\title{
VALIDASI REKAHAN SEBAGAI INDIKATOR BATUAN TERUBAH DENGAN METODE KELURUSAN DAN PETROGRAFI DI DAERAH BUNGBULANG, KABUPATEN GARUT, PROVINSI JAWA BARAT
}

\section{FRACTURES VALIDATION AS ALTERED ROCKS INDICATOR BY LINEAMENT AND PETROGRAPHY METHOD IN BUNGBULANG, GARUT REGENCY, WEST JAVA PROVINCE}

\author{
Puspa Khaerani ${ }^{1}$, Andra Taufiq ${ }^{1}$, Dicky Muslim², Faisal Helmi ${ }^{1}$, Yunitha R. I. Putri ${ }^{2}$ \\ ${ }^{1}$ Program Sarjana Teknik Geologi, Universitas Padjadjaran, Indonesia \\ ${ }^{2}$ Program Pascasarjana Teknik Geologi, Universitas Padjadjaran, Indonesia \\ pkhaerani@gmail.com
}

\begin{abstract}
ABSTRAK
Garut Selatan menyimpan potensi sumber daya mineral berupa emas, krisopras, dan kalsedon. Di beberapa lokasi di Bungbulang ditemukan adanya batuan terubah dan tambang kalsedon tradisional yang sudah tidak beroperasi lagi yaitu di Sungai Citanggeuleuk. Batuan terubah ini memiliki ciri fisik litologi yang berbeda dengan batuan di sekitarnya seperti berwarna hitam, mengandung mineral muskovit, klorit, dan mineral lempung. Lokasi singkapan batuan terubah diperkirakan berada pada jalur rekahan sesar minor di daerah tersebut. Tujuan penelitian ini untuk mengungkap adanya rekahan yang diperkuat dengan adanya batuan terubah sebagai jalur fluida hidrotermal.
\end{abstract}

Metode yang digunakan dalam penelitian ini yaitu kelurusan dan petrografi. Metode kelurusan yang digunakan berupa analisis kelurusan segmen sungai sebagai analisis dasar kelurusan yang mengindikasikan adanya anomali kelurusan pada lokasi penelitian. Metode petrografi dilakukan untuk mengidentifikasi mineral pada batuan yang menunjukkan adanya pengaruh ubahan karena rekahan.

Dari kegiatan pemetaan geologi di daerah penelitian terdapat indikasi batuan terubah di beberapa tempat pada litologi batupasir dan tuf yang mengandung mineral mika putih yang melimpah, klorit, dan mineral lempung. Dari hasil analisis morfometri sungai di daerah ini, diinterpetasikan rekahan yang mempengaruhi pembentukan batuan terubah ini berarah barattimur yang memanjang dari Sungai Citanggeuleuk sampai Sungai Cianda. Maka rekahan merupakan indikator adanya batuan terubah pada daerah Bungbulang, Garut.

Kata kunci: batuan terubah, Bungbulang, Garut, petrografi, rekahan, kelurusan

\section{ABSTRACT}

Southern Garut deposits mineral resources in the form of gold, chrysophrase, and chalcedony. In some places, can be discovered some outcrops that has been altered by hydrothermal fluid. There is also a traditional chalcedony mining than has already been closed near the Citanggeuleuk River. This altered rock has different physical characteristic, compared with other rock around. The altered rock has black color and contained several minerals, such as muscovite, chlorite, and clay mineral. It is estimated that the alteration is caused by the minor fault and fracture path in the outcrop area. The aim is to reveal the fracture in the study area validated by altered rock as a path of hydrothermal fluid.

This research used lineament method and petrography method. Lineament method that used in this study is river segment lineament as basic analysis to indicate lineament anomaly. 
Petrography method is used to identify mineral in rock sample that indicate an alteration by fracture.

Based on the geological mapping in the outcrop area, there are indications of altered mineral in several places that have sandstones and tuff lithology. These rocks contained big amounts of white mica, chlorite, and clay mineral. From the lineament analysis, it is interpreted that the fracture affected the formation of these altered rocks to drift into a west-east trend that extend from Citanggeuleuk River to Cianda River. The conclusion of this research is that the fracture proven by altered rocks in Citanggeuleuk River, Bungbulang, Garut.

Keywords: altered rocks, Bungbulang, Garut, petrography, fracture, lineament

\section{PENDAHULUAN}

Garut Selatan menyimpan sumber daya mineral berupa emas, kalsedon, krisopras, dan lain sebagainya. Bungbulang merupakan daerah penghasil batu akik terbesar di Jawa Barat, salah satunya adalah kalsedon. Kalsedon merupakan salah satu jenis batuan terubah yang berasal dari kriptokristalin kuarsa (Efendi, dkk., 2015). Batuan terubah disebabkan oleh perubahan mineralogi sebagai hasil interaksi dari batuan dengan fluida hidrotermal. Fluida hidrotermal dapat bersirkulasi sepanjang jalur rekahan atau sesar (Lagat, 2009).

Analisis kelurusan citra landsat merupakan salah satu metode yang digunakan untuk melihat tingginya anomali kerapatan struktur geologi suatu daerah yang berhubungan dengan adanya patahan dan/atau rekahan (Hermawan dan Rezky, 2011). Namun pada penelitian ini penulis menggunakan interpretasi kelurusan segmen sungai pada daerah penelitian. Interpretasi kelurusan segmen sungai ini dipakai karena aliran sungai cenderung mengikuti zona lemah berupa sesar atau kekar yang muncul sebagai kelurusan (Liu dan Mason, 2016). Suatu kelurusan dapat mengindikasi adanya struktur retas (dyke) yang berkembang, kekar, foliasi, bidang perlapisan, dan lain sebagainya. Kelurusan ini merupakan suatu indikator tapi belum terbukti (Hunt, 2007). Suatu kelurusan segmen sungai dapat mempresentasikan rekahan atau kekar pada suatu daerah (van der Pluijm, 2004 dalam Utomo, dkk., 2016). Suatu fenomena tektonik dapat diwakilkan dari suatu kelurusan segmen sungai dan azimuth kelurusannya (Hirnawan, dkk., 2010).

\section{GEOLOGI REGIONAL}

Daerah penelitian tersusun atas empat satuan batuan dari tua ke muda yaitu Diorit Kuarsa, Formasi Bentang, Breksi Tufaan, dan Batuan Gunungapi Tua Tak Teruraikan (Alzwar, dkk., 1992). Diorit Kuarsa (Tmi(d)) berupa intrusi diorit bertekstur porfiritik, terubah menjadi serisit dan piroksen, serta diorit. Satuan ini berumur Miosen Tengah. Formasi Bentang (Tmbp) tersusun atas batupasir tufan, tuf batuapung, batulempung, konglomerat, dan lignit berumur Miosen Tengah - Pliosen. Breksi Tufaan (Tpv) yang tersusun atas breksi, tuf, dan batupasir berumur Pliosen. Batuan Gunungapi Tua Tak Teruraikan (QTV) tersusun atas tuf, breksi tuf, dan lava. Lava bersusunan andesit dan basalt. Sumber asli batuan gunungapi ini tidak dapat dijelaskan. Satuan ini berumur Pliosen Pleistosen.

Struktur geologi regional yang mempengaruhi keadaan geologi regional daerah Garut dan sekitarnya menurut Alzwar, dkk. (1992) yaitu sesar normal dan sesar geser. Sesar geser umumnya berorientasi baratdaya-timurlaut yang melibatkan satuan batuan berumur Tersier dan Kuarter sehingga dapat ditafsirkan sebagai sesar yang muda.

Kelurusan merupakan gambaran atau pola dalam suatu bukti faktual seperti peta atau citra permukaan bumi maupun bawah permukaan bumi dengan pola yang lurus dan berkelanjutan sehingga dapat 
ditentukan titiknya, lebarnya, dan azimutnya dan berhubungan dengan kenampakan pada permukaan bumi (Caran, dkk., 1982). Beberapa anak sungai, vegetasi, tanah, dan pecahan relief yang lurus berhubungan dengan pola pada ilmu geologi sehingga dapat diinterpretasikan sebagai suatu kelurusan (Caran, dkk., 1981 dalam Caran, dkk., 1982). Kelurusan diasumsikan sebagai bidang lemah yang berasosiasi dengan sesar atau rekahan yang menjadi jalur pergerakan fluida yang berasal dari reservoir yang muncul di permukaan sebagai manifestasi seperti mata air panas atau fumarol (Utomo, dkk., 2016). Kelurusan ini sangat berhubungan dengan dengan struktur geologi yang jelas terlihat pada kenampakan di permukaan bumi (Caran, dkk., 1982).

Batuan teralterasi dapat diartikan sebagai batuan yang mengalami perubahan mineralogi dikarenakan adanya interaksi antara batuan dengan fluida hidrotermal. Fluida hidrotermal dapat bersirkulasi sepanjang rekahan (Lagat, 2009). Kumpuan mineral alterasi dalam sedimen terdiri dari mineral lempung dan mika (Miller, dkk., 2013).

Menurut Van Ruitenbeek, dkk. (2005, dalam Miller, dkk., 2013) kandungan Al relatif dalam mika putih dapat menandakan posisi panjang gelombang absorpsi $\mathrm{AlOH}$ dan perubahan temperatur, pergantian kimia fluida hidrotermal, dan komposisi mineral dari tipe batuan induk. Klorit merupakan mineral terubah yang memiliki rentang temperatur yang panjang yaitu berkisar dari $>120^{\circ} \mathrm{C}$ (Modifikasi Reyes, 1990 dalam Lagat, 2009).

Sesar dan rekahan dapat tertutupi oleh alterasi atau endapan mineral yang dibawa oleh air termal. Kenampakan manifestasi permukaan yang dapat mengindikasikan sesar atau rekahan sebagai jalur aliran fluida yaitu alterasi permukaan, endapan mineral (sinter silica), dan kemunculan mata air panas dan fumarol (Suryantini dan Wibowo, 2010).

\section{METODOLOGI}

Interpretasi kelurusan segmen sungai merupakan salah satu variabel dalam menentukan suatu daerah rekahan (Hirnawan, dkk., 2010). Kelurusan segmen sungai dapat diukur densitas datanya menggunakan rosette diagram sehingga diketahui arah dominan segmen sungai tersebut yang diindikasikan sebagai rekahan. Sungai yang dipakai dalam interpretasi merupakan hasil digitasi dari Peta RBI Digital Lembar Bungbulang.

Analisis petrografi dilakukan untuk mengidentifikasi batuan yang diinterpretasikan mengalami ubahan. Sampel batuan untuk analisis petrografi dilakukan pada 4 lokasi. Identifikasi mineral secara miroskopis dilakukan sehingga diketahui persentase mineral primer maupun mineral sekunder dalam batuan tersebut.

\section{HASIL DAN PEMBAHASAN}

Berdasarkan pemetaan geologi yang dilakukan, daerah penelitian tersusun atas empat satuan batuan yaitu:

a) Lava Basalt (Qlb)

b) Satuan Breksi Vulkanik (Tpbv)

c) Satuan Breksi (Tmbx)

d) Satuan Intrusi Dasit (Tid)

Litologi yang terinterpretasi mengalami ubahan tersebar pada satuan breksi dan satuan breksi vulkanik. Tambang kalsedon yang ditemukan di lapangan terdapat pada litologi breksi vulkanik.

Beberapa lokasi di daerah penelitian diinterpretasikan telah mengalami alterasi baik pada batuan vulkanik maupun batuan sedimen yaitu pada stasiun P61 berupa batupasir, stasiun P62 berupa breksi sedimen, stasiun P44 berupa batupasir, stasiun P56 berupa tuf. Batuan yang terindikasi terubahkan ini dianalisis secara petrografi sebagai tindak awal penentuan ada tidaknya mineral ubahan dalam batuan tersebut. Salah satu mineral penciri suatu batuan telah teralteasi yaitu adanya mineral lempung. 


\section{MAKALAH ILMIAH}

Secara umum batuan piroklastik pada daerah penelitian telah mengalami ubahan karena adanya temperatur yang meningkat. Hal ini membuktikan batuan piroklastik pada daerah penelitian berumur tua sehingga telah mengalami proses geologi yang cukup panjang dan menyebabkan mineral penyusunnya mengalami ubahan.

Tatanan tektonik pada bagian selatan Pulau Jawa pun menjadi penyebab dari terubahkannya sebagian besar litologi pada daerah penelitian. Hal ini terbukti dari banyaknya kelurusan segmen sungai sehingga menghasilkan offset horizontal dari suatu sungai yang diindikasikan berpotensi sebagai rekahan.

Kelurusan segmen sungai pada daerah penelitian di beberapa lokasi tertentu mengindikasikan adanya intensitas tektonik yang tinggi. Kelurusan segmen sungai ini mengindikasikan adanya rekahan di daerah penelitian.

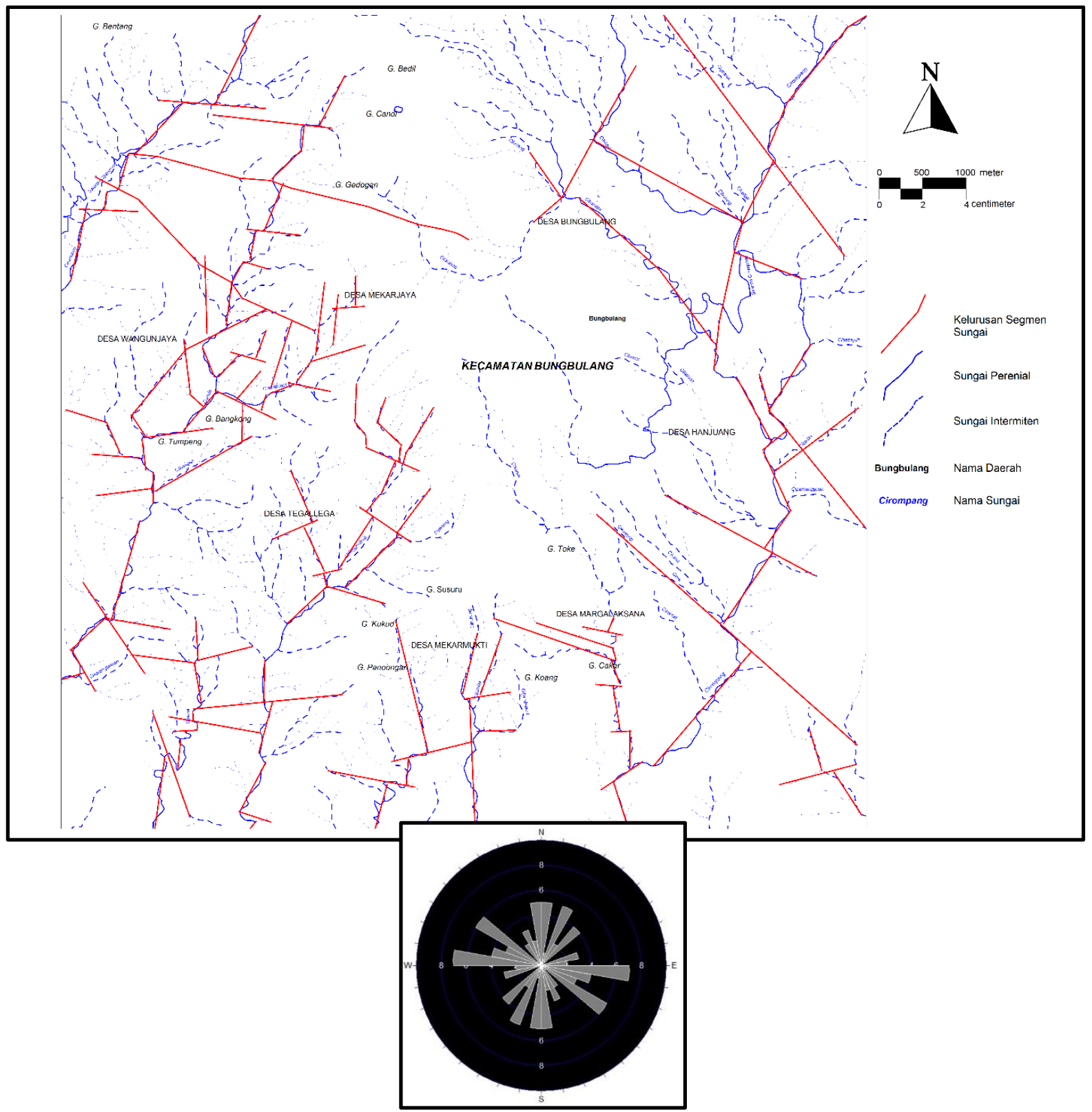

Gambar 1. Interpretasi kelurusan segmen sungai dan rosette diagram pada daerah penelitian 
Dari analisis kelurusan segmen sungai dihasilkan rosette diagram yang dapat menggambarkan arah tegasan dominan rekahan yang ada di daerah penelitian yaitu tenggara - baratlaut dan barat - timur. Hal ini berhubungan dengan ditemukannya batuan terubah pada stasiun P61, P62, P44, dan P56. Stasiun batuan tersebut tersebar ke arah barat dari Sungai Citanggeuleuk sampai Sungai Cianda.

Indikasi rekahan dari kelurusan ini juga diperkuat dengan adanya air terjun di dekat Sungai Cianda dan tambang kalsedon yang sudah tidak beroperasi lagi di dekat Sungai Citanggeuleuk.

Kedua sungai diinterpretasikan memiliki intensitas rekahan yang cukup dominan dengan ditemukannya batuan terubah di lapangan. Namun berdasarkan interpretasi mineral ubahan yang ditemukan berupa kalsedon yang terbentuk pada temperatur $70^{\circ} \mathrm{C}$ s.d. $180^{\circ} \mathrm{C}$ maka mineralisasi pada daerah Bungbulang ini masih tergolong ke dalam mineral yang terbentuk dalam temperatur yang stabil (Hedenquist, 1996 dalam Efendi, dkk., 2015).

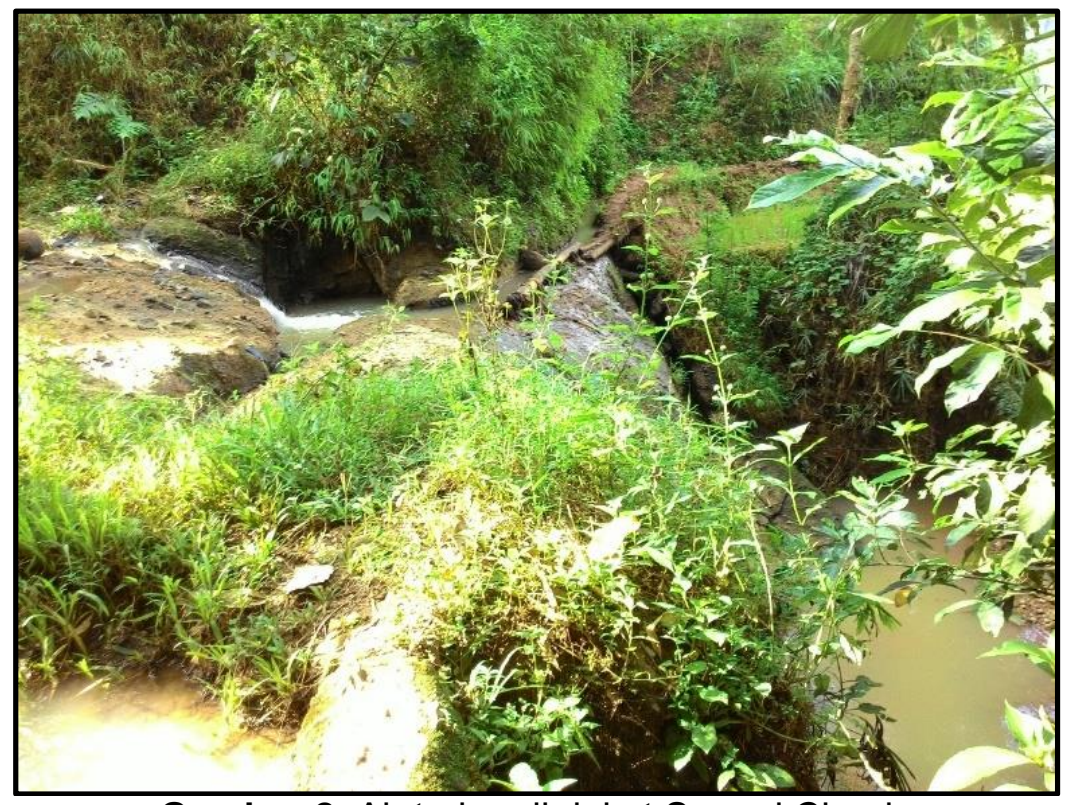

Gambar 2. Air terjun di dekat Sungai Cianda

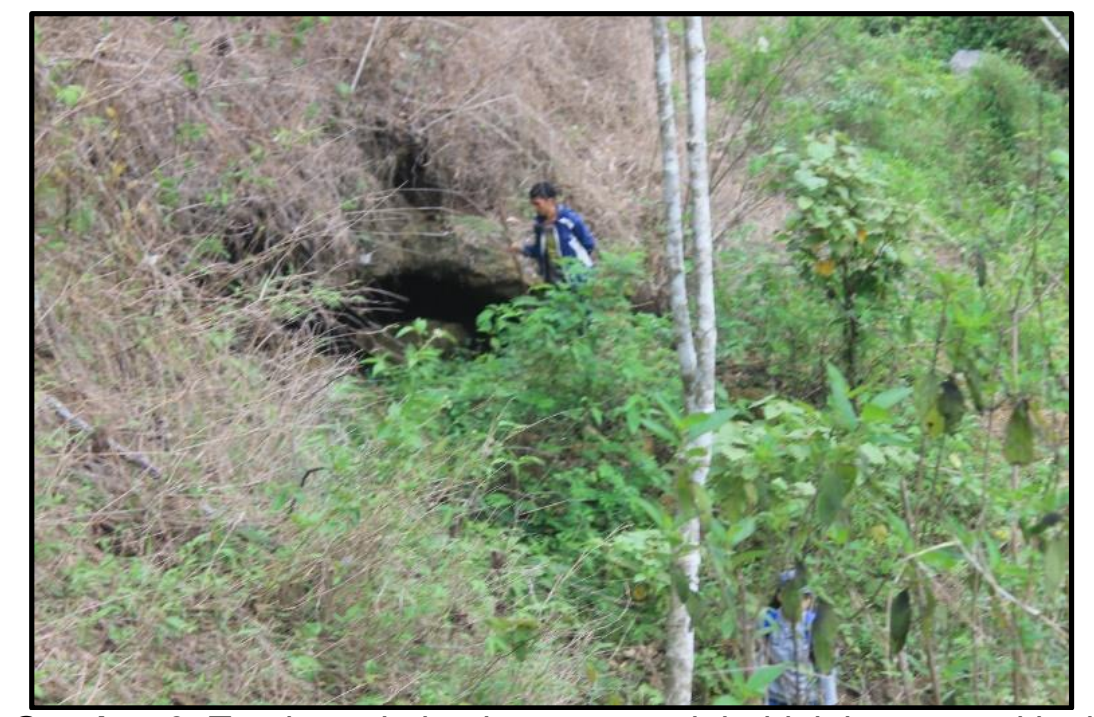

Gambar 3. Tambang kalsedon yang sudah tidak beroperasi lagi di dekat Sungai Citanggeuleuk 


\section{MAKALAH ILMIAH}
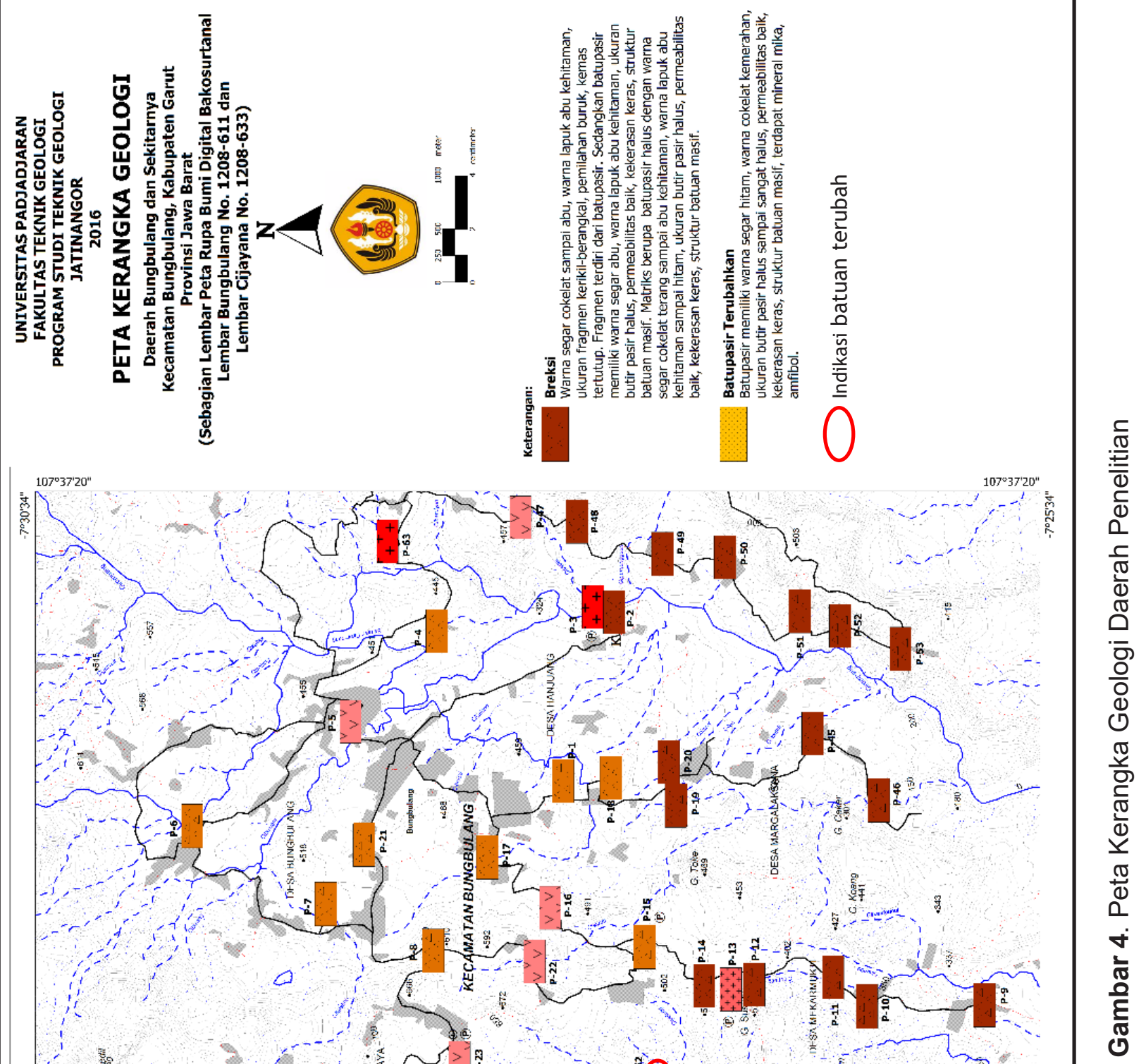


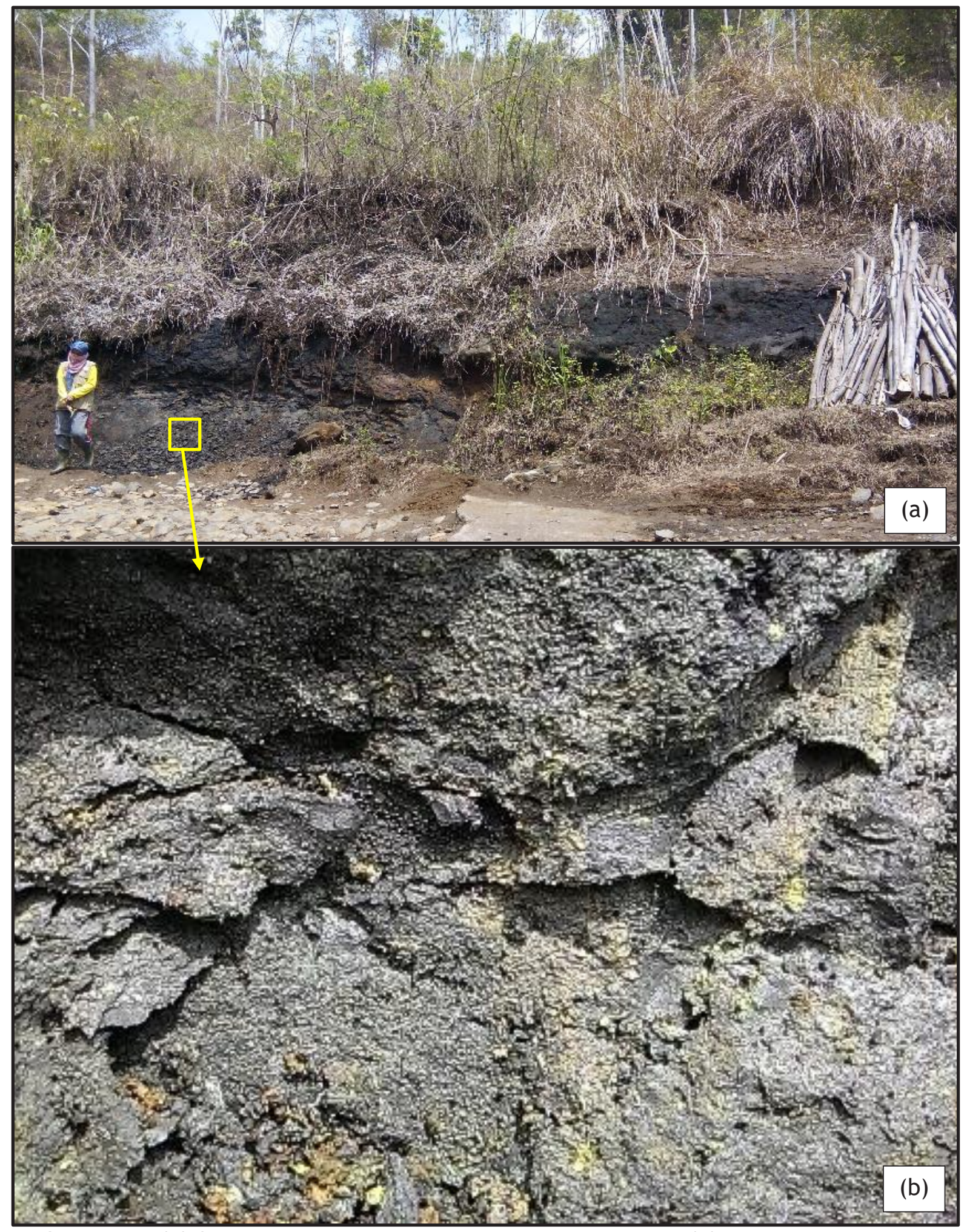

Gambar 5. (a) Singkapan batupasir terubah pada stasiun P61; (b) Warna hitam batuan menunjukkan adanya ubahan material vulkanik dan warna coklat menunjukkan oksidasi hasil lapukan batuan 


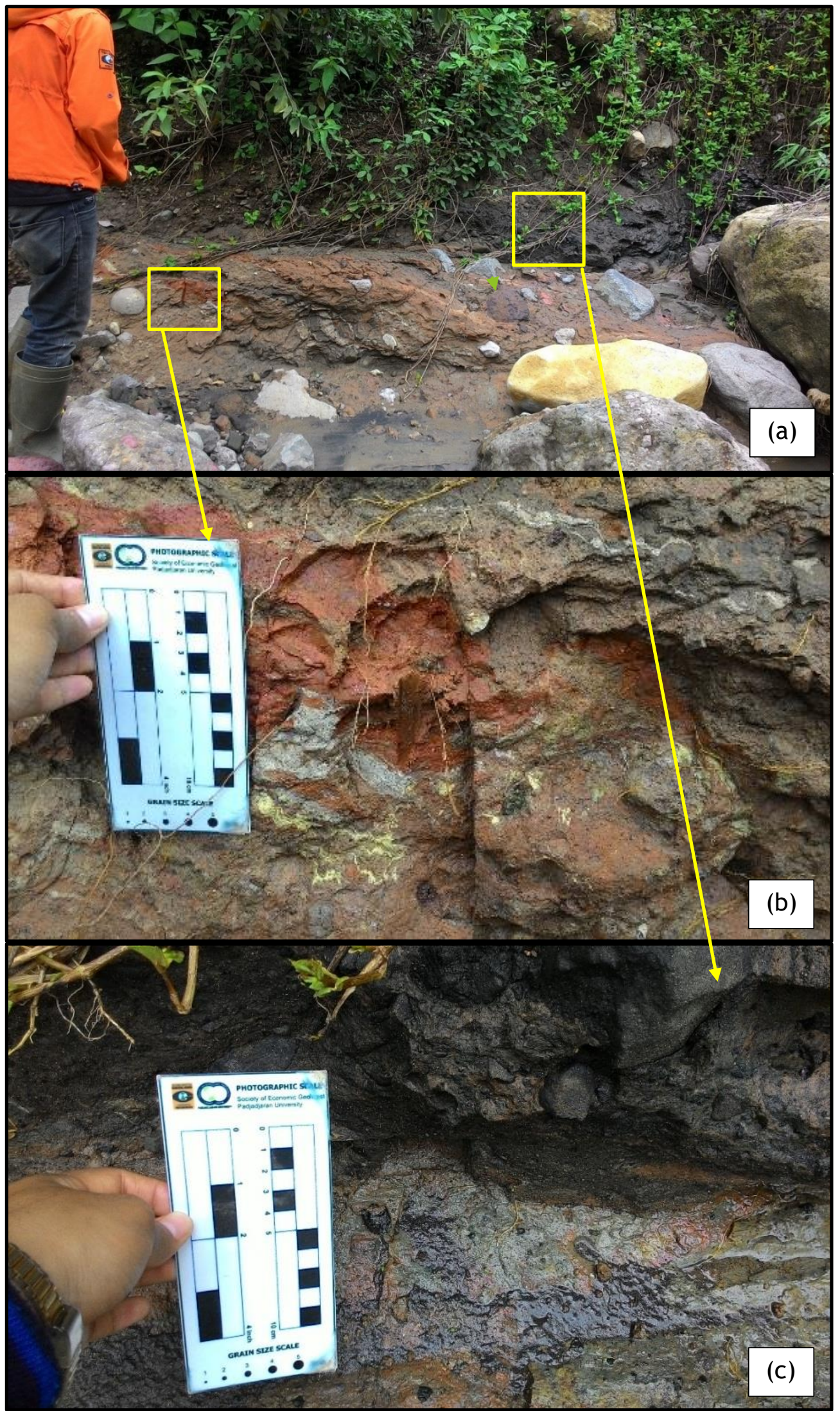

Gambar 6. (a) Singkapan breksi terubah pada stasiun P62. (b) Kenampakan batuan berwarna merah kemerahan akibat oksidasi menghasilkan mineral lempung;

(c) Kenampakan batuan berwarna hitam akibat ubahan material vulkanik 


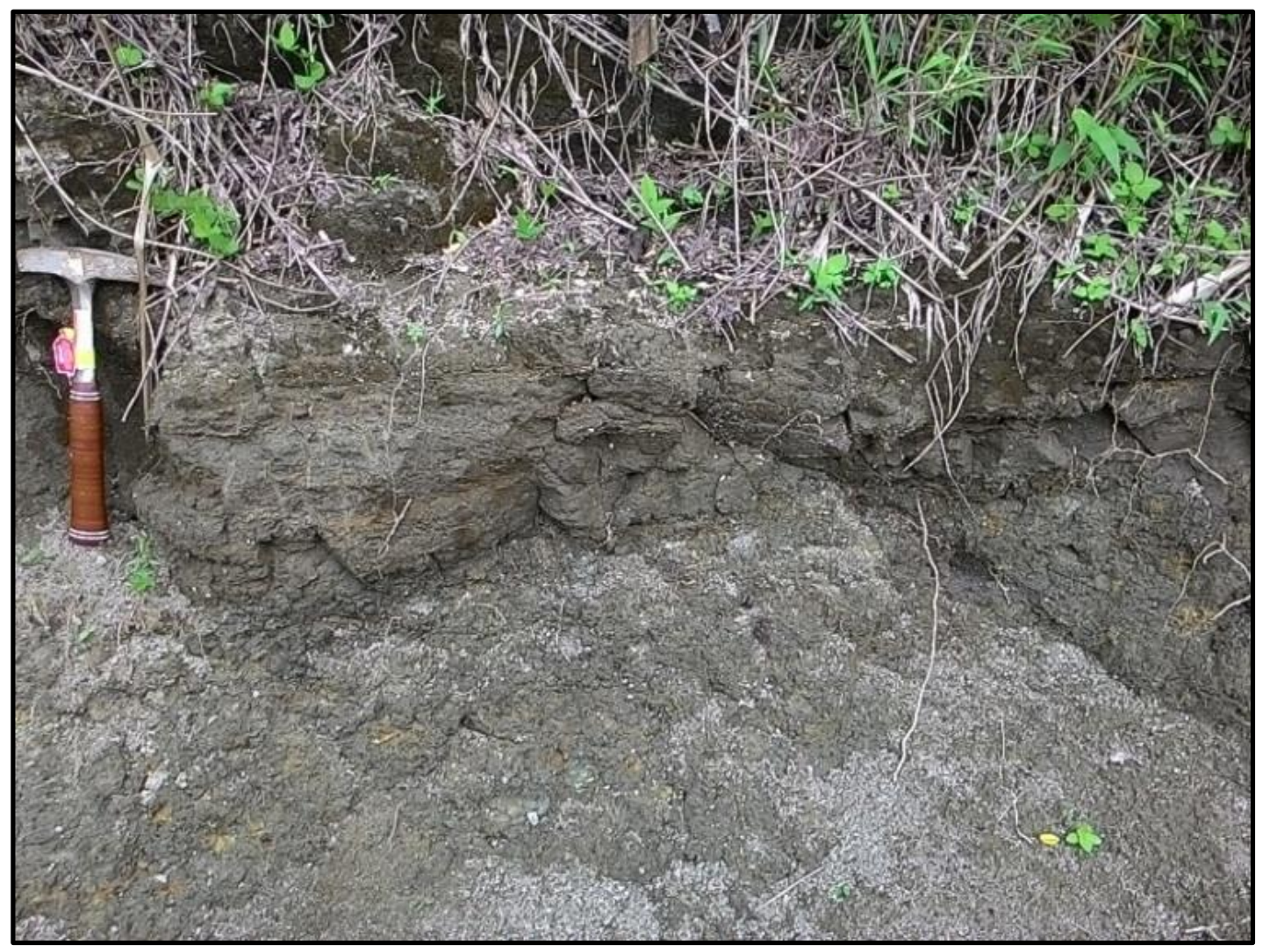

Gambar 7. Singkapan batupasir terubah pada Stasiun P44 berwarna abu kehitaman

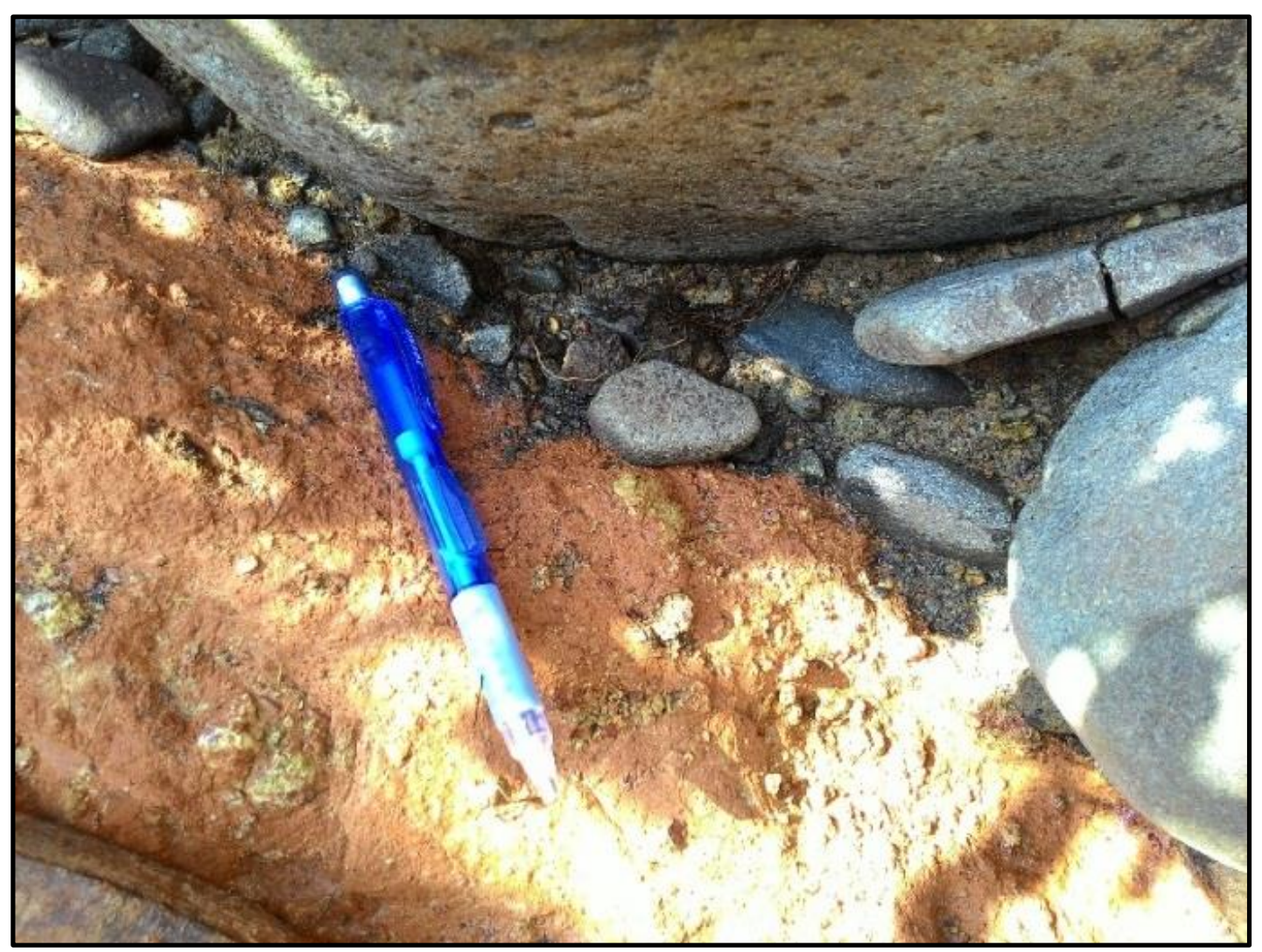

Gambar 8. Singkapan tuf terubah pada stasiun P56 warna coklat kemerahan menunjukkan kehadiran mineral lempung 
Batuan yang diterindikasi terubahkan ini

data sebagai berikut:

dianalisis secara petrografi dan dihasilkan

Tabel 1. Persentase Analisis Petrografi Batuan Terubah

Persentase Mineral (\%)

\begin{tabular}{|c|c|c|c|c|c|c|c|c|c|c|c|c|}
\hline \multirow[b]{2}{*}{$\begin{array}{l}\text { Nama } \\
\text { Stasiun }\end{array}$} & & & & 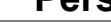 & 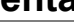 & - & 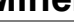 & ( & & & & \multirow[b]{2}{*}{ Keterangan } \\
\hline & 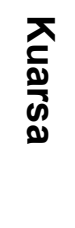 & $\begin{array}{l}\frac{0}{0} \\
\frac{0}{0} \\
\frac{0}{\bar{\alpha}} \\
\frac{\hat{\theta}}{\omega}\end{array}$ & $\begin{array}{l}P \\
\frac{1}{10} \\
\frac{\Phi}{0} \\
\frac{0}{0} \\
\frac{0}{2} \\
\stackrel{2}{7}\end{array}$ & 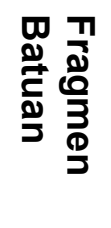 & 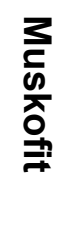 & $\begin{array}{l}\text { 品 } \\
\stackrel{ \pm}{ \pm}\end{array}$ & 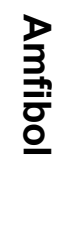 & 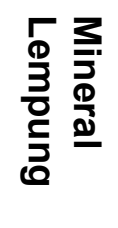 & $\begin{array}{l}\text { 증 } \\
\frac{0}{7}\end{array}$ & $\begin{array}{l}\frac{0}{3} \\
\overline{0} \\
\frac{0}{\hat{\lambda}} \\
\Phi \\
\frac{1}{2}\end{array}$ & $\begin{array}{l}\text { 융 } \\
\text { 읏 }\end{array}$ & \\
\hline P61 & 5 & 13 & 5 & 5 & 5 & - & 5 & 35 & 10 & 3 & 14 & $\begin{array}{l}\text { Feldspathic } \\
\text { greywacke }\end{array}$ \\
\hline P62 & 5 & 5 & 3 & 10 & 3 & 1 & - & 59 & 10 & 1 & 3 & Lithic Wacke \\
\hline P44 & 13 & 6 & 10 & 10 & - & - & - & 60 & - & - & 1 & $\begin{array}{l}\text { Feldspathic } \\
\text { Greywacke }\end{array}$ \\
\hline P56 & & $\mathrm{k} 1$ & & $\begin{array}{l}(10 \% \\
\text { gmen }\end{array}$ & ; Kri & & (Kua & $\begin{array}{l}\text { rsa } 8^{\circ} \\
) \text {, Mat }\end{array}$ & $A-F$ & & $\begin{array}{l}5 \%, \\
\%)\end{array}$ & Lithic Tuff \\
\hline
\end{tabular}

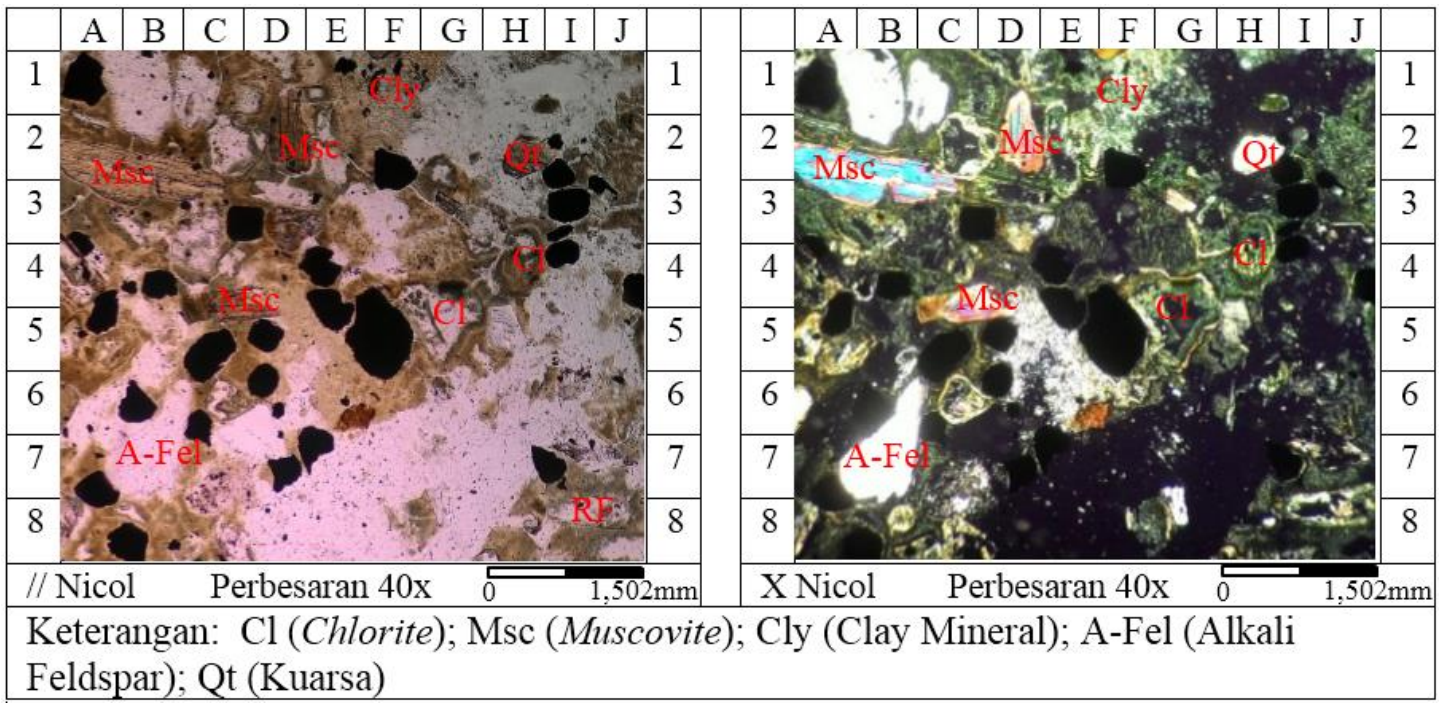

Gambar 9. Petrografi Sayatan Batupasir Stasiun P61

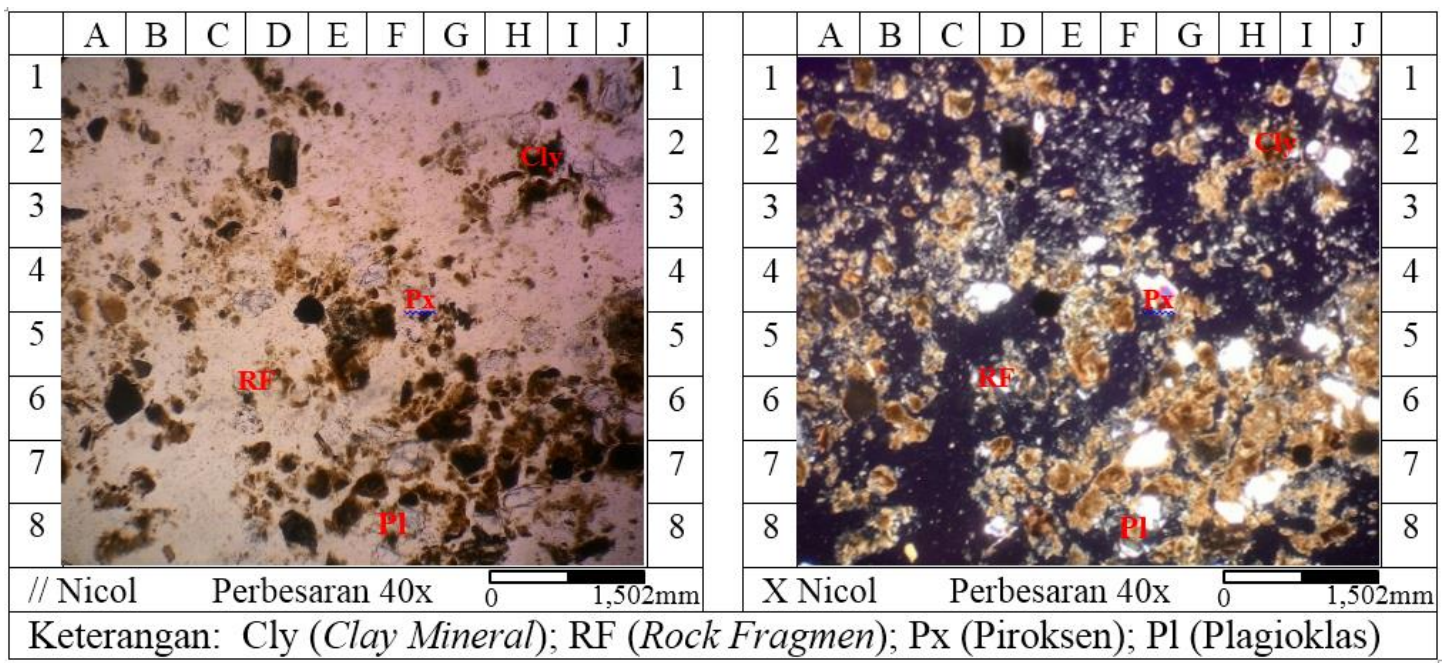

Gambar 10. Petrografi Sayatan Batupasir Stasiun P62 


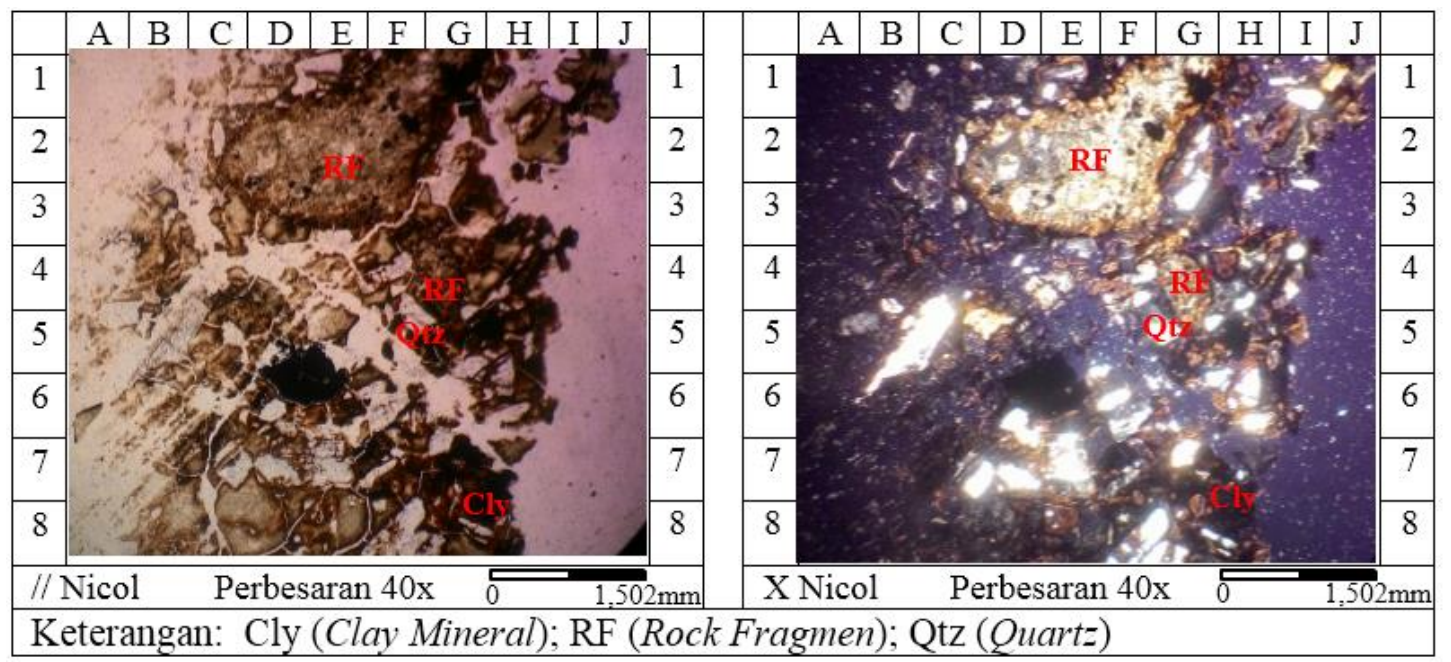

Gambar 11. Petrografi Sayatan Batupasir Stasiun P44

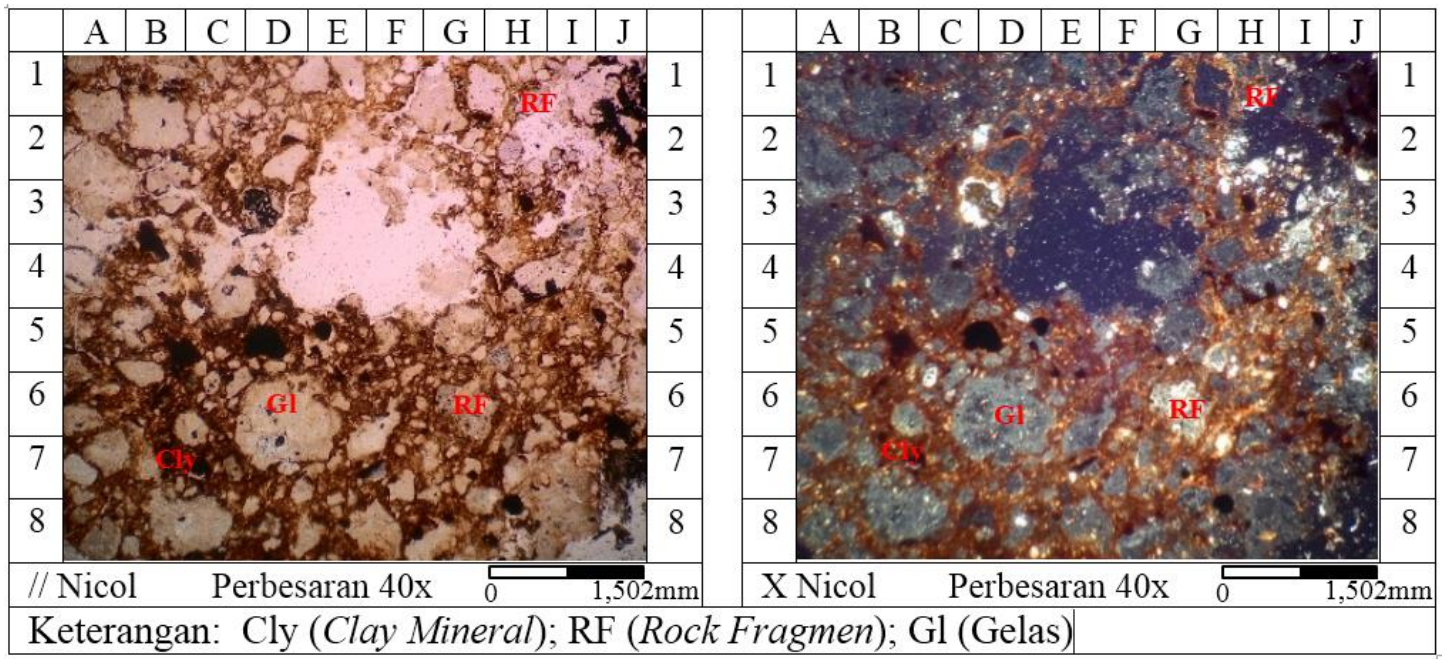

Gambar 12. Petrografi Sayatan Batupasir Stasiun P56

Dari analisis petrografi diinterpretasikan beberapa batuan telah mengalami ubahan yang cukup signifikan seperti pada stasiun P61 yang banyak mengandung mineral mika, klorit, dan mineral lempung. Di dekat stasiun P61 ini terdapat tambang kalsedon warga setempat yang sudah tidak beroperasi lagi. Dari keempat sayatan litologi yang mengindikasikan adanya batuan terubah ini, hanya satu yang berupa material piroklastik yaitu pada stasiun P56. Berdasarkan klasifikasi Pettijohn (1975 dalam Nichols, 2009) litologi pada stasiun P61 dan P44 berupa feldspathic greywacke sedangkan P62 berupa lithic wacke, dan P56 berupa tuf litik (Schmidt, 1981 dalam
Gillespic and Stylus, 1999).

Menurut Van Ruitenbeek dkk. (2005, dalam Miller, dkk., 2013) kandungan Al relatif dalam mika putih dapat menandakan posisi panjang gelombang absorpsi $\mathrm{AlOH}$ dan perubahan temperatur, pergantian kimia fluida hidrotermal, dan komposisi mineral dari tipe batuan induk. Beberapa fragmen gelas pada sayatan batupasir sudah terubah menjadi klorit terlihat di sekeliling fragmen gelas yang berwarna hijau. Klorit merupakan mineral terubah yang memiliki rentang temperatur yang panjang yaitu berkisar dari $>120^{\circ} \mathrm{C}$ (Modifikasi dari Reyes, 1990 dalam Lagat, 2009). 


\section{MAKALAH ILMIAH}

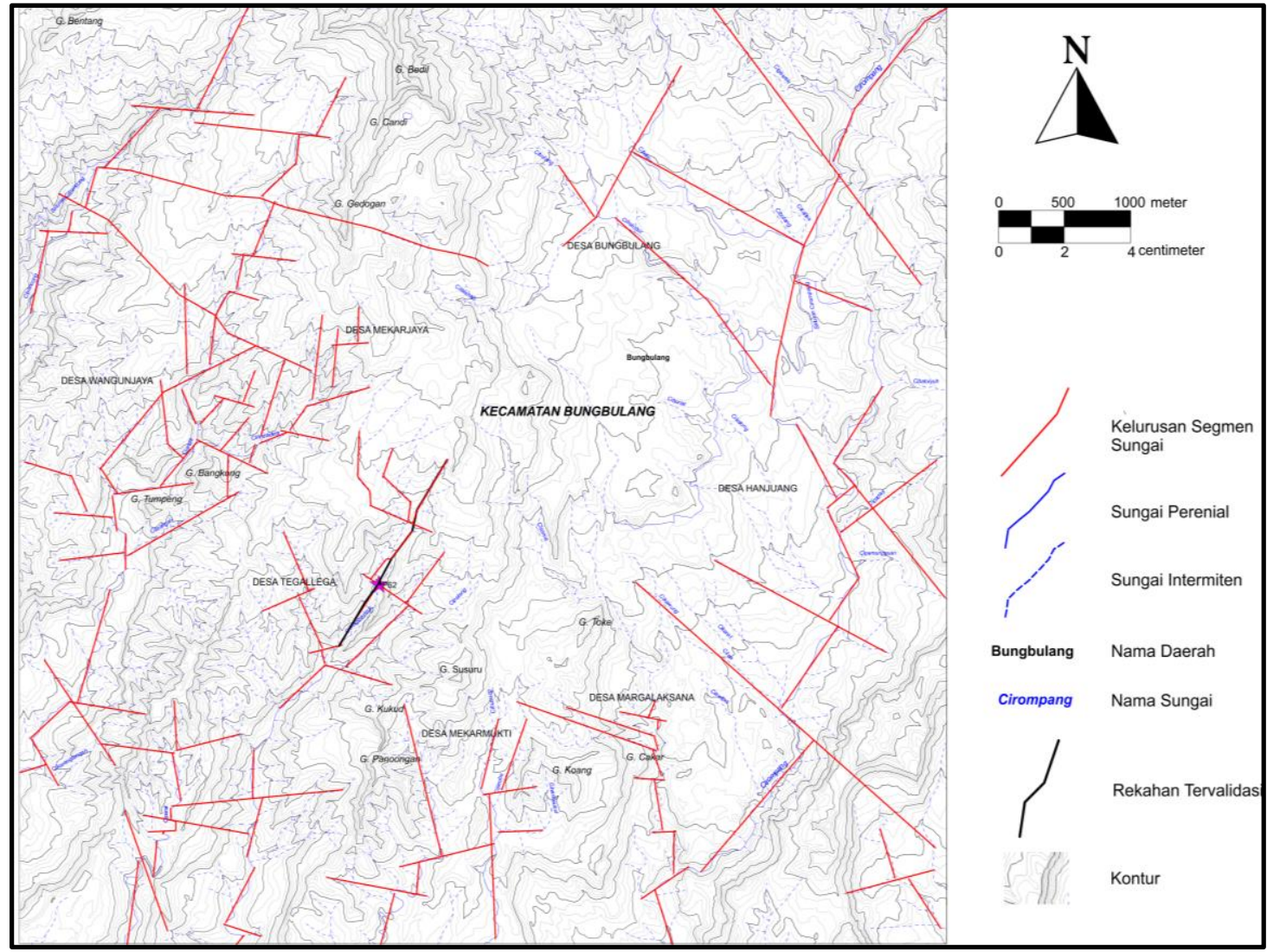

Gambar 13. Peta Validasi Kelurusan Segmen Sungai di Daerah Penelitian

\section{KESIMPULAN}

Batuan terubah pada stasiun P61 dan tambang kalsedon yang sudah tidak aktif menjadi bukti adanya rekahan pada kelurusan segmen sungai di daerah tersebut. Hal ini memungkinkan adanya sumber daya mineral yang belum tereksplorasi pada kelurusan segmen sungai tersebut.

\section{UCAPAN TERIMA KASIH}

Penulis mengucapkan banyak terima kasih kepada tim editor yang telah membantu dalam penyempurnaan makalah dan kepada dewan redaksi atas dimuatnya makalah dalam buletin ini.

\section{DAFTAR PUSTAKA}

Alzwar, M., Akbar, N., dan Bachri, S., 1992. Peta Geologi Lembar Garut dan Pameungpeuk, Jawa. Pusat Penelitian dan Pengembangan Geologi.
Caran, S. C., Woodruff, C. M., dan Thompson, E. J. 1982. Lineament Analysis and Inference of Geological Structure - Examples from the Balcones/Ouachita Trend of Texas. Gulf Coast Association of Geological Societies, Vol. XXXI, Texas, Bureau of Economic Geology.

Efendi, R., Anilahi, T., Budiana, T., Syafri, I., Sulistyawan, R.I.H., 2015. Alteration Zone Relationship to Distribution of Gemstones from Bungbulang Garut Based on Petrographic and XRF Analysis. Proceeding, Seminar Nasional Kebumian Ke-8, Hal. 566 - 577.

Gillespic, M.R., and Styles, M.T. 1999. Classification of Igneous Rocks. Dalam: BGS Rock Classification Scheme, Volume I, British Geological Survey Research Report (2 ${ }^{\text {nd }}$ Edition), British Geological Survey, Keyworth, Nottingham NG12, UK, h. 1-52. 
Lagat, J., 2009. Hydrothermal Alteration Mineralogy in Geothermal Fields With Case Examples from Olkaria Domes Geothermal Field, Kenya. Dipresentasikan dalam Short Course IV on Exploration for Geothermal Resources.

Hermawan, D. dan Rezky, Y., 2011. Delineasi Daerah Prospek Panas Bumi Berdasarkan Analisis Kelurusan Citra Landsat di Candi Umbul - Telomoyo, Provinsi Jawa Tengah. Buletin Sumber Daya Geologi, Vol. 6 No. 1 Hal. 1 - 10.

Hirnawan, F., Muslim, D., dan Sukiyah, E., 2010. A Measure of Intense Active Tectonism Through Manifestation of River Basin Morphometry Development on Quaternary Volcanic Deposits (4235) - Case study : at Ciremai and Slamet Volcanoes. FIG Congress 2010. Pp. $1-17$.

Hunt, Roy E., 2007. Characteristics of Geological Materials and Formations A Field Guide for Geotechnical Engineers. CRC Press, Taylor \& FrancisGroup.

Liu, J.G. dan Mason, P. J., 2016. Image Processing and GIS for Remote Sensing, Techniques and Applications, Second Edition. UK: Wiley Blackwell.
Miller, J. K., Haselwimmer, C., dan Prakash, A., 2013. Investigating LowTemperatur Hydrothermal Alteration in Drill Cuttings from Pilgrim $\mathrm{Hot}$ Springs, Alaska, Using a Suit of Low Cost Analytical Technique. GRC Transactions, Vol. 37, Pp. 989 - 996.

Nichols, G., 2009. Sedimentology and Stratigraphy. United Kingdom: Blackwell Publishing.

Supangat, A. B., 2012. Karakteristik Hidrologi Berdasarkan Parameter Morfometri DAS di Kawasan Taman Nasional Meru Betiri.

Suryantini dan Wibowo, H. H., 2010. Application of Fault and Fracture Density (FFD) Method for Geothermal Exploration in NonVolcanic Geothermal System; A Case Study in Sulawesi - Indonesia. Proceedings World Geothermal Congress, Pp. $1-9$.

Utomo, Y. H., Haryanto, I., Sukiyah, E., dan Sunardi, E., 2016. Analisis Tingkat Kerentanan Gerakan Tanah Menggunakan Modifikasi Metode Storie Di Wilayah Cisompet dan Sekitarnya, Kabupaten Garut. Seminar Nasional Ke-III Fakultas Teknik Geologi Universitas Padjadjaran.

\begin{tabular}{|ll|}
\hline Diterima & $: 15$ September 2016 \\
Direvisi & $: 20$ Oktober 2016 \\
Disetujui & $: 14$ November 2016
\end{tabular}

